\title{
Framing Sustainability in a Telecoupled World
}

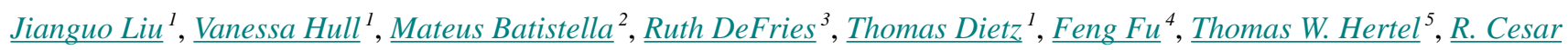 \\ Izaurralde $^{6}$, Eric F. Lambin $^{7}$, Shuxin Li $^{1}$, Luiz A. Martinelli ${ }^{8}$, William J. McConnell $^{1}$, Emilio F. Moran ${ }^{1}$, Rosamond Naylor \\ ${ }^{7}$, Zhiyun Ouyang ${ }^{9}$, Karen R. Polenske ${ }^{4}$, Anette Reenberg $^{10}$, Gilberto de Miranda Rocha $^{11}$, Cynthia S. Simmons ${ }^{1}, \underline{\text { Peter H. }}$. \\ Verburg $^{12}$, Peter M. Vitousek ${ }^{7},{ }_{\text {Fusuo Zhang }}{ }^{13}$ and Chunquan Zhu ${ }^{14}$
}

ABSTRACT. Interactions between distant places are increasingly widespread and influential, often leading to unexpected outcomes with profound implications for sustainability. Numerous sustainability studies have been conducted within a particular place with little attention to the impacts of distant interactions on sustainability in multiple places. Although distant forces have been studied, they are usually treated as exogenous variables and feedbacks have rarely been considered. To understand and integrate various distant interactions better, we propose an integrated framework based on telecoupling, an umbrella concept that refers to socioeconomic and environmental interactions over distances. The concept of telecoupling is a logical extension of research on coupled human and natural systems, in which interactions occur within particular geographic locations. The telecoupling framework contains five major interrelated components, i.e., coupled human and natural systems, flows, agents, causes, and effects. We illustrate the framework using two examples of distant interactions associated with trade of agricultural commodities and invasive species, highlight the implications of the framework, and discuss research needs and approaches to move research on telecouplings forward. The framework can help to analyze system components and their interrelationships, identify research gaps, detect hidden costs and untapped benefits, provide a useful means to incorporate feedbacks as well as trade-offs and synergies across multiple systems (sending, receiving, and spillover systems), and improve the understanding of distant interactions and the effectiveness of policies for socioeconomic and environmental sustainability from local to global levels.

Key Words: agents; causes; coupled human-environment systems; coupled human and natural systems; coupled socialecological systems; dispersal; distant interactions; effects; feedbacks; flows; globalization; investment; knowledge transfer; migration; socioeconomic and environmental interactions; species invasion; sustainability; technology transfer; teleconnection; telecoupling; trade; transnational land deals; water transfer

\section{INTRODUCTION}

The world has undergone dramatic changes and increased interactions over long distances in recent decades, often with profound impacts on socioeconomic and environmental sustainability (Reid et al. 2010). A poignant example involves biofuels. Biofuel mandates, such as in the European Union (EU) and the United States, have significant ramifications for food prices and carbon footprints because producing biofuel domestically may take land away from food production and importing large quantities of biomass over long distances, e. g., imports to EU from Africa, Asia, and the Americas, emits substantial amounts of $\mathrm{CO}_{2}$ and affects land use elsewhere (Banse et al. 2008). The increase in food prices and overall reduction in food production due in part to the growing demand for biofuels (Feng and Babcock 2010, Swinton et al. 2011) contributed to global food shortages in 2008 and civil unrest in many nations. In response to social and environmental externalities, the scientific community and policy makers have begun to put forth policies and mitigation measures. However, major scientific and policy challenges remain with regard to creating timely responses that could prevent negative impacts from occurring at all. To address such challenges, we need improved understanding and the ability to predict distant interactions and their consequences in all places.

Distant environmental interactions have existed since the formation of planet earth, and distant socioeconomic interactions have occurred since the beginning of human history. However, distant interactions such as trade, transnational land deals, spread of invasive species, and technology transfer are now more prevalent, and occur more quickly, than ever before (Liu et al. 2007a; Appendix 1). For instance, many subsistence needs, e.g., food such as grain and fish and water resources, historically met by local resource uses are now being met by increased global trade (Kastner et al. 2011, Konar et al. 2011). In the past several decades, the world's total food exports have increased tenfold (United Nations Statistics Division 2012).

\footnotetext{
${ }^{1}$ Michigan State University, USA, ${ }^{2}$ EMBRAPA Satellite Monitoring, Campinas, SP, Brazil, ${ }^{3}$ Columbia University, USA, ${ }^{4}$ Massachusetts Institute of Technology, USA, ${ }^{5}$ Purdue University, USA, ${ }^{6}$ University of Maryland, USA, ${ }^{7}$ Stanford University, USA, ${ }^{8}$ CENA University of São Paulo (USP), Piracicaba, São Paolo, Brazil, ${ }^{9}$ Chinese Academy of Sciences, Beijing, China, ${ }^{10}$ University of Copenhagen, Copenhagen, Denmark, ${ }^{11}$ Federal University of Pará, Brazil, ${ }^{12}$ Institute for Environmental Studies, VU University Amsterdam, Netherlands, ${ }^{13}$ China Agricultural University, Beijing, China, ${ }^{14}$ International Union for Conservation of Nature, China
} 
Distant interactions also occur in completely new contexts (Appendix 1). For example, the world's urban population increased from 1.02 billion in 1960 to 3.56 billion in 2010 (United Nations Department of Economic and Social Affairs 2012), with 2.54 billion more people now depending on food and other resources from places outside urban areas, and often from across the world. Economic activities increased sevenfold from 1950 to 2010 (Nelson 2005). Many large countries such as China, India, and Brazil were poor three decades ago, but have now emerged as global economic powerhouses. The explosive development and use of social media have empowered and connected individuals across the world, with highly unpredictable socioeconomic and environmental consequences.

Distant interactions pose unprecedented challenges and opportunities for sustainability. They increasingly affect issues of global importance, such as climate change, biodiversity, food security, land use, poverty alleviation, public health, social unrest, and water scarcity. For example, international trade accounts for $30 \%$ of threats to species globally (Lenzen et al. 2012). Although a number of countries, such as China, have experienced forest transitions, e.g., a shift from net forest loss to net forest recovery, these transitions often occur at the cost of forests in other countries through trade of forest and agricultural products (Zhu and Feng 2003, Zhu et al. 2004, Rudel et al. 2009, DeFries et al. 2010, Lambin and Meyfroidt 2011). Impacts of climate change on agriculture are predicted to be most significant in regions where food demands are growing the fastest, e.g., China, requiring trade to bridge the gap between food production and food consumption (Jones and Thornton 2003). More water transfer projects are being built to address water crises in regions plagued by water scarcity, including the world's largest and longest one, China's South-North Water Transfer Scheme, which aims for 45 billion $\mathrm{m}^{3}$ of annual water transfer with a planned investment of US\$ 77 billion (Liu and Yang 2012). At the same time, expansion of information technology and networks has promoted democracy ( $\mathrm{Li}$ and Reuveny 2003), availability of cellular phones that allow for connections with distant partners has improved trade opportunities for local shareholders (Aker 2008), and global health networks have made vaccines increasingly available for remote communities (Milstien et al. 2006). In addition, the rapid growth of ecocertification, sustainability standards, and sustainable sourcing strategies by large agribusiness corporations offer a potentially countervailing trend to the increase of commodity trade, by harnessing the forces of globalization for sustainability (Giovannucci and Ponte 2005, Van Kooten et al. 2005).

Understanding distant interactions is a direct response to international calls for transforming the concept of sustainable development into practice (United Nations SecretaryGeneral's High-level Panel on Global Sustainability 2012).
Although there has been separate and fragmented research on some aspects of distant interactions, there are numerous important knowledge gaps, e.g., those identified by the National Academy of Sciences (National Research Council 2012), which called for evaluating impacts of global trade on the environment, e.g., ecosystem services, and human wellbeing, e.g., health. Distant forces have been sometimes considered, but they were often treated as exogenous variables (United Nations Secretary-General's High-level Panel on Global Sustainability 2012). Expanded distant interactions across the world require a new research framework to fill knowledge gaps and advance sustainability science and applications (Kates et al. 2001, Turner et al. 2003). We propose a new integrated framework for advancing our understanding of various distant interactions and instantiate it with two illustrative examples. We also highlight the implications of this framework for research and policy on sustainability from local to global levels. Finally, we discuss research needs and general approaches to move research forward.

\section{CONCEPTUAL FRAMEWORK OF TELECOUPLINGS AND SUSTAINABILITY}

Interactions between distant natural or human systems have been studied in many disciplines. For instance, the concept of teleconnections has been used in atmospheric sciences (Glantz et al. 1991) to refer to environmental interactions among climatic systems across long distances, such that changes in climate at one place influence places hundreds or thousands of kilometers away through atmospheric circulation (Fig. 1A). On the other hand, economic globalization (Levitt 1983; Fig. 1B) or socioeconomic interactions between distant human systems, has long been studied by social scientists. Although such separate studies on distant socioeconomic or environmental interactions have produced useful insights, they also have led to oversights (Adger et al. 2009, Eakin et al. 2009).

Fig. 1. Definitions of teleconnections, globalization, and telecouplings.

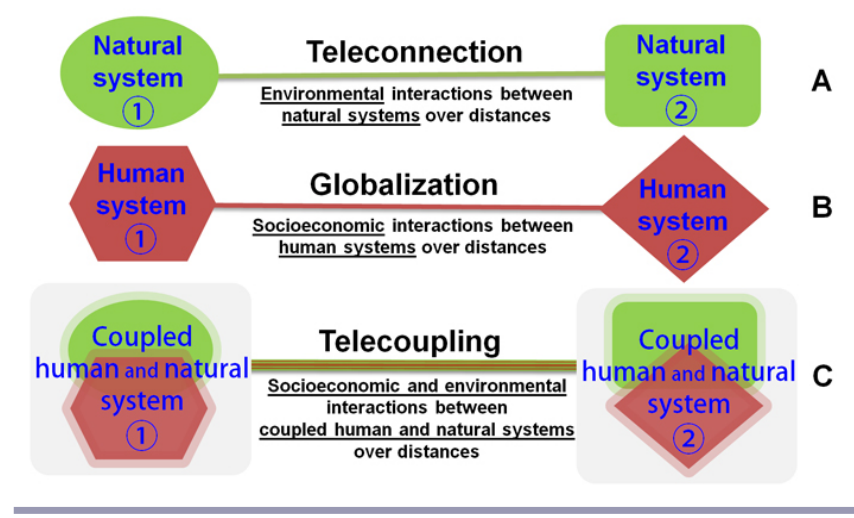


Sustainability can be understood better when different types of interactions are integrated across multiple coupled human and natural systems (National Science Foundation Advisory Committee for Environmental Research and Education 2009). We use an integrated concept, telecoupling (Liu et al. 2011), to encompass both socioeconomic and environmental interactions among coupled human and natural systems over distances (Fig. 1C). The concept of telecoupling is a logical extension of research on coupled human and natural systems (Liu et al. 2007b, Alberti et al. 2011), coupled socialecological systems (Walker et al. 2004), or coupled humanenvironment systems (Turner et al. 2003, Moran 2010). Telecoupling is also a unifying concept that builds upon previous concepts such as teleconnection, globalization, and world systems theory (Hornborg et al. 2007, Dreher et al. 2008), which have largely been limited to single disciplines (but see Adger et al. 2009, Seto et al. 2012).

To understand telecoupling, we propose an integrated framework. Telecoupled systems are hierarchically structured, so the telecoupling framework takes a multilevel analytic approach. At the telecoupled system level, it includes an interrelated set of coupled human and natural systems that are connected through flows among them (Fig. 2). At the coupled system level, each coupled system consists of three interrelated components: agents, causes, and effects (Fig. 2). At the component level, each component includes many elements or dimensions. For example, agents have different types, e.g., individuals, households, organizations, corporations, and there are socioeconomic and environmental effects. Furthermore, there are cross-level interactions, e.g., agents within coupled systems facilitate flows among coupled systems, and flows among coupled systems produce effects within coupled systems.

Causes produce a telecoupling between coupled human and natural systems, which generates socioeconomic and environmental effects that are manifested in coupled human and natural systems. The telecoupling is made possible by agents that facilitate or hinder the flows of material/energy and/or information among systems. Agents and causes can affect each other. As Figure 2 indicates, causes and effects are connected by feedback loops, but separating cause from effect can be a useful analytical simplification. Furthermore, although some components, e.g., agents, causes, and effects, are nested within a coupled system, treating them as separate components from systems can help highlight their roles in telecouplings and their relationships with other components. We illustrate the telecoupling framework using two detailed examples of distant interactions (Table 1): one is dominated and initiated by humans intentionally, and the other is biologically dominated and initiated by humans unintentionally.
The first example, soybean trade, concerns the increasing trade of soybeans from Brazil to China. Chinese soybean imports grew from $\sim 14$ million tons in 2000 to $\sim 46$ million tons in 2010 (United States Department of Agriculture Foreign Agricultural Service 2010). Currently more than $80 \%$ of soybeans used by China's food industry are imported from other countries, mainly from Brazil and the U.S. (Zhang and Liu 2009, Brown-Lima et al. 2010). The soybean trade between Brazil and China plays an important role in global trade markets and prices, carbon emissions, ecosystem services, and livelihoods in many coupled human and natural systems in China, Brazil, and beyond.

Fig. 2. Five major and interrelated components of the telecoupling framework. The telecoupled system is hierarchically structured and is influenced by within-level and cross-level interactions. At the telecoupled system level, it includes a set of interacting coupled human and natural systems through flows. At the coupled system level, it consists of three interrelated components, agents, causes, effects. At the component level, each component has different attributes. Causes produce a telecoupling between at least two coupled human and natural systems, which generate effects that are manifested in one or more coupled human and natural systems. The telecoupling is made possible by agents nested within the systems that facilitate or hinder the unidirectional or bidirectional flows of material/energy or information among systems. Systems can be defined as sending, receiving, and/or spillover systems, depending on the directional movement of the flow considered. For the sake of simplicity, structure and processes, e.g., local couplings, within a coupled system are not shown except those that are directly related to telecouplings between systems.

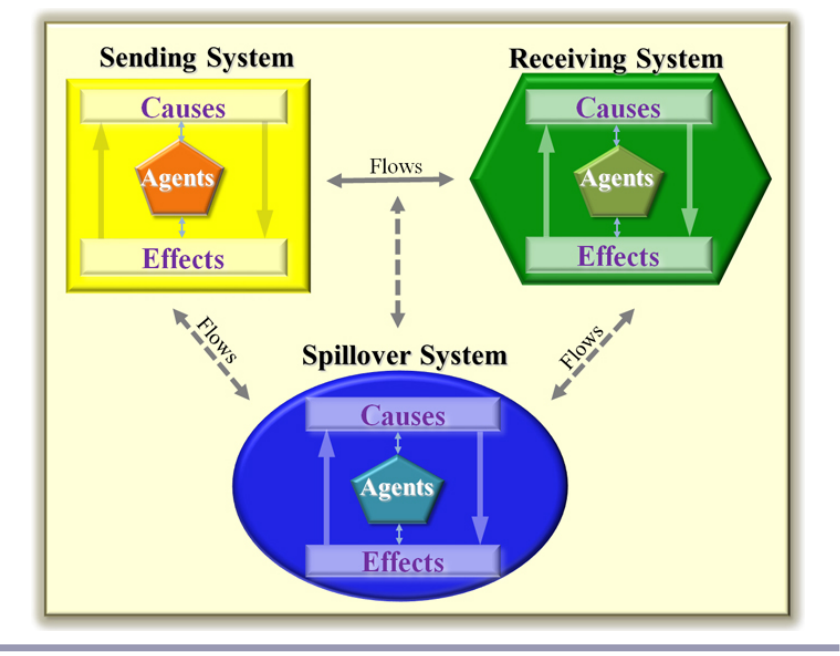


Table 1. Summary of five major components in the two examples (Soybean trade between Brazil and China, and Red imported fire ant [RIFA] invasion).

\begin{tabular}{|c|c|c|c|}
\hline & & Soybean trade & Red imported fire ant (RIFA) invasion \\
\hline Systems & $\begin{array}{l}\text { Sending } \\
\text { Receiving } \\
\text { Spillover }\end{array}$ & $\begin{array}{l}\text { - Brazil } \\
\text { - China } \\
\text { - United States, some unknown countries }\end{array}$ & $\begin{array}{l}\text { - South America } \\
\text { - United States } \\
\text { - Some unknown countries }\end{array}$ \\
\hline Flows & Material/Energy & $\begin{array}{l}\text { - soybeans } \\
\text { - money } \\
\text { - fossil fuels in transportation }\end{array}$ & - pesticides \\
\hline & Information & $\begin{array}{l}\text { - prices } \\
\text { - agricultural techniques }\end{array}$ & - invasion control methods \\
\hline Agents & & $\begin{array}{l}\text { - farmers } \\
\text { - governments } \\
\text { - companies }\end{array}$ & $\begin{array}{l}\text { - ants } \\
\text { - traders } \\
\text { - farmers }\end{array}$ \\
\hline Causes & $\begin{array}{l}\text { Economic } \\
\text { Political } \\
\text { Technological } \\
\text { Environmental } \\
\text { Cultural }\end{array}$ & $\begin{array}{l}\text { - China's demand for soybeans } \\
\text { - government interest in investment } \\
\text { - improved tropical agricultural technology } \\
\text { - differences in climate } \\
\text { - cultural preference for soybeans }\end{array}$ & $\begin{array}{l}\text { - demand for tradable goods } \\
\text { - government promotion of international trade } \\
\text { - advancement in transportation modes } \\
\text { - aggressive nature of species } \\
\text { - preference for foreign goods }\end{array}$ \\
\hline Effects & Environmental & $\begin{array}{l}\text { - loss of biodiversity and ecosystem services } \\
\text { - } \mathrm{CO}_{2} \text { emissions } \\
\text { - unknown effects in spillover systems } \\
\text { - intensive land use } \\
\text { - displacement of local people } \\
\text { - farmers' gain / loss of income from soybeans } \\
\text { - unknown effects in spillover systems }\end{array}$ & $\begin{array}{l}\text { - biodiversity loss } \\
\text { - agricultural crop loss } \\
\text { - unknown effects in spillover systems } \\
\text { - agricultural income loss } \\
\text { - property damage } \\
\text { - unknown effects in spillover systems }\end{array}$ \\
\hline
\end{tabular}

The second example is the red imported fire ant (RIFA) invasion. The RIFA (Solenopsis invicta) is listed as one of the "100 worst invasive species" by the International Union for Conservation of Nature (IUCN; Lowe et al. 2000). It reduces biodiversity and causes over US\$ 6 billion in damage in the U.S. alone each year, mainly by damage to agriculture (Ascunce et al. 2011). The fire ant originates from South America and was first accidentally introduced to the U.S. on cargo ships in the early 1900's (Ascunce et al. 2011). It spread widely throughout the southern part of the country soon after being introduced, and has recently further spread to Australia, New Zealand, China, and elsewhere (Ascunce et al. 2011).

Although we highlight two distinct examples of telecoupling below, we emphasize that different telecouplings may interact with one another. Some of them may enhance each other, while others offset each other. Some may induce further telecouplings, while others may eliminate them. For instance, studies have indicated there are close relationships between trade and species invasions. On one hand, trade is one of the major causes of species invasions (Crosby 1986, Nentwig 2007). On the other hand, species invasions have led to feedbacks including restrictions and inspections of traded goods and products, with calls for stronger measures such as tradable permit programs (Horan and Lupi 2005) and invasive species tariffs (Margolis et al. 2005) in the future.

\section{Systems}

Systems refer to coupled human and natural systems or integrated systems in which humans and nature interact (Liu et al. 2007b). Although each system is in a geographic location (place), has specific contexts, and consists of many human and natural elements as well as processes (e.g., climatic and soil conditions, habitats, accessibility, topographic features such as slopes and elevation, economic and political institutions and policies, and local couplings between human and natural elements), we focus on attributes that are directly related to telecouplings between systems. For each telecoupling, systems can act as sending systems, receiving systems, or spillover systems. Sending systems can be thought of as origins, sources, or donors and receiving systems as destinations or recipients (Fig. 2). Sending systems refer to those from which flows of material, energy, or information move outward, e.g., exporting countries, whereas receiving systems are those that obtain flows from the sending systems, e.g., importing countries. Of course, which system is defined as sending and which as receiving depends on the flow being analyzed.

Spillover systems are systems that affect and/or are affected by the interactions between sending and receiving systems. Spillover systems may be connected to sending and receiving systems in at least three main ways: by being an intermediate stopover between the two systems, e.g., migratory bird stopover or port and airport connections; by being in the 
pathway between the sending and receiving systems, e.g., oil spill by tanker in transit; or by interacting with sending and/ or receiving systems in other ways, e.g., third party in trade agreement (Fig. 3). A system can also be a sending system for one telecoupling and a receiving or spillover system for another telecoupling.

Fig. 3. Example typologies of relationships between sending, receiving, and spillover systems. (A) represents one-one-one relationship and (B) represents select manymany-many relationships. Arrows indicate directions of flows. More arrows are possible between sending, receiving, and spillover systems but are omitted for the sake of simplicity. Spillover systems may be connected to sending and receiving systems in at least three ways: by being in the pathway between the sending and receiving systems (e.g., oil spill by tanker in transit; straight dashed arrow), by being an intermediate stopover between the sending and receiving systems (e.g., migratory bird stopover or airport layover; long-dashed curvy arrow), or by interacting with sending and/or receiving systems in other ways (e.g., third party in transnational land deals; short-dashed curvy arrow). (a)

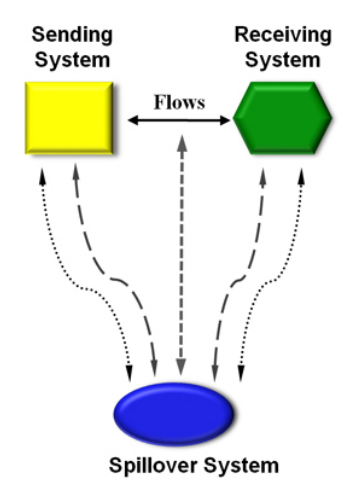

(b)

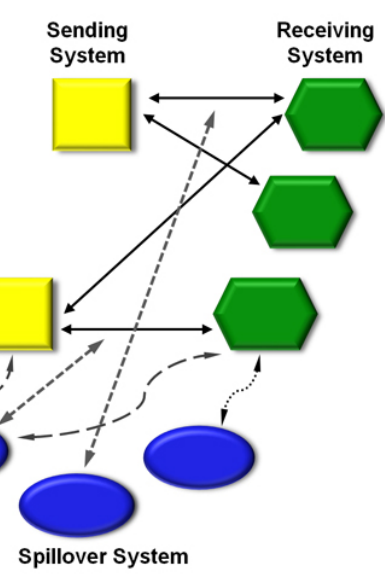

In the soybean trade example, Brazil can be considered the sending system for soybean flow because it produces the soybeans and China is the receiving system because it receives the soybeans and soybean products. However, for the flows involving financial transactions for soybean production, China is the sending system and Brazil the receiving. These relationships can be seen in market transactions with products flowing in one direction and money flowing in the other direction. However, little research has been done on spillover systems, which may include every other country around the world that has historically been involved in soybean trade, such as the United States. The U.S. in particular may have been affected as a result of the cheaper costs of producing soybeans as well as technological advances in tropical agriculture in developing countries like Brazil, which competes with soybean production in the U.S. In the RIFA invasion example, South America is the sending system because that is the native habitat of the RIFA. The U.S., the first foreign country that the RIFA invaded, is the main receiving system.

The interrelationships among sending, receiving, and spillover systems are complex. In terms of the numbers of sending, receiving, and spillover systems in a telecoupled system, they may be one-one-zero (one sending, one receiving, and no spillover system), one-one-one (one sending, one receiving, and one spillover system; Fig. 3A), a mix of one and many systems (e.g., one-one-many in the case of market effects because bilateral trade may have widespread effects), or manymany-many (many sending, many receiving, and many spillover systems; Fig. 3B). The latter are the most complex because there are not only interactions among sending, receiving, and spillover systems, but also interactions among sending systems, among receiving systems, and among spillover systems. In addition, for the same telecoupling over time, a receiving system can become a new sending system. In the RIFA invasion example, the U.S. could either be considered a receiving system or a sending system, depending on the time period in question, because it was initially a receiving system but later developed into a sending system that enhanced the spread of the species to other countries. In fact, global populations of the RIFA have been genetically traced back to U.S. populations as opposed to originating directly from South America (Ascunce et al. 2011). For these complex interactions, it is key to characterize not only system composition, but also temporal and spatial configurations of the telecoupled system to better understand flows, agents, causes, and effects.

\section{Flows}

Flows are movements of material, energy, or information between the systems that are transferred as a result of actions taken by agents. Material and energy include biogeophysical entities, e.g., manufactured goods, food, natural resources, organisms, and biofuels, and information consists of knowledge, trade agreements, financial data, genes, and agricultural techniques. Flows can be unidirectional or bidirectional and can follow pathways that proceed directly between sending and receiving systems, or indirectly between the two by passing through spillover systems (Figs. 2 and 3).

In the soybean trade example, the main material flows include shipping of soybeans and soybean products from Brazil to China, and examples of information flows are financial transactions and trade agreements between Brazil, China, and other countries. In the case of the RIFA invasion, the main material flows involved are movement of goods for trade, ants themselves, and pesticides and other materials used to control the spread of the invaders. Information flows include the dissemination of knowledge about the damages caused by the ants and how to control the spread. 
Flows can leapfrog from sending systems to distant receiving systems. This occurred with the soybean trade example involving the distant countries Brazil and China, which are $20,000 \mathrm{~km}$ apart by sea. Flows can also begin with receiving systems located closer to the sending systems, and radiate outward over time to more distant receiving systems. This can be illustrated by the case of the RIFA invasion's initial stages of gradual spread of the invader from the south and southeastern U.S., the initial receiving system, to California, although it leapfrogged later on when spreading from California to other countries.

Networks of infrastructure, institutions, and ecosystems play important roles in dictating the pathways that flows take as they proceed from one system to another. They include transport networks, e.g., roads, boats, vehicles, airplanes; intergovernmental networks, e.g., trade agreements; facilitators of trade, e.g., electronic customs clearances (Hertel and Mirza 2009); social networks, e.g., epistemic scientific communities (Haas 1993); and ecological networks, e.g., animal migration pathways. In the case of soybean trade, the networks allowing the flows of soybeans from Brazil to China include financial, social, transportation and government networks.

\section{Agents}

Agents, or actors, include autonomous decision-making entities that directly or indirectly facilitate or hinder telecouplings, such as via the emergence or dissolution of flows. The telecoupling framework highlights the variety of agents and the intricate connections between the agents distributed across sending, receiving, and spillover systems. Agents facilitate or prevent flows that produce, maintain, amplify, weaken, or dissolve telecouplings. They can be individuals or groups of humans or animals, e.g., socioeconomic units such as households, or organizations such as government agencies, or flocks or herds of animals.

In the soybean trade example, the main agents include soybean producers, agribusinesses, and public and private investors and their supporters in Brazil, financial investors and consumers of soybean products in China, and the respective government agencies involved in creating and enforcing trade agreements. In the case of the RIFA invasion, the main agents consist of traders who inadvertently helped spread the insect, the farmers and policy makers in the United States and spillover systems who attempt to limit further spread, e.g., by conducting control operations, and the ants that have evolved characteristics that outcompete many other insects and make them highly successful as invaders of the new habitats into which they were inadvertently introduced.

Agents form relationships with one another to produce flows that shape the telecouplings. For human agents, these may operate through social networks such as governments, institutions, private corporations, personal friendships, and kinship (Jackson and Watts 2002). For instance, relationships between governments and corporations are important to drive bilateral trade flows between Brazil and China in the soybean trade example (Niu 2010). For animal agents, there are also forms of communication that facilitate interactions. In the RIFA invasion example, individual ants use sophisticated chemical communication to coordinate activities of the colony that allow for expansion into new systems (Vander Meer et al. 2002).

For establishing new telecouplings, innovative agents that are flexible in their requirements may be most often successful, but different characteristics, such as resilience, may matter more for maintaining and strengthening an existing telecoupling. Alien species like the RIFA take hold and become invasive in receiving systems when they thrive in new biotic conditions and outcompete natives for limited resources (Callaway and Ridenour 2004). The soybean trade between Brazil and China has thrived in part because the flexible trade agreements adopted by Brazil and China allow the systems to adapt to new markets and opportunities, and because there are highly effective commodity value chains linking producing regions with the main markets abroad.

\section{Causes}

The causes of a telecoupling are factors that influence its emergence and dynamics, e.g., changes in strength. Most telecouplings have more than one cause. A cause may originate in a sending, receiving, or spillover system (Fig. 2). A cause can be classified as proximate or ultimate (Laland et al. 2011). Political, economic, cultural, technological, or ecological change can produce new dynamics in the telecoupled system and all of these changes are intertwined. Shifts in preferences can alter demand, technological innovations and diffusions can alter supply, and the interplay of supply in the sending system and demand in the receiving system can shape the system dynamics. Changes in institutions including policies and rules can induce or retard interaction with a distant system. Ecological factors play important roles in telecouplings. Causes also interact with effects via feedback mechanisms.

There are multiple causes of the soybean trade telecoupling. One of the main economic causes is a demand for soybean products, e.g., vegetable oil and animal feed in China and a supply of land, water, and capital for soybean production in Brazil. A political cause is the Chinese government's interest in pursuing foreign investments and the Brazilian government's interests in developing the export market. A cultural cause is preferences for soybean products and animal products, resulting from soybeans as animal feed, by the Chinese people. Technological causes include agronomic advances mostly by Embrapa, the Brazilian Agricultural Research Corporation, which invested heavily in developing tropical agriculture technology to cope with acid Cerrado soils, and the development of soybean varieties adapted to 
these latitudes that are able to biologically fix nitrogen from the atmosphere (Alves et al. 2003, 2006). In addition, development of supply chains and rapid advancements in the efficient storage and long distance transport of agricultural products like soybeans in recent years have also facilitated this telecoupling. An ecological cause is the good climatic conditions for growing soybeans in Brazil.

For the RIFA invasion telecoupling, one of the main economic causes is an increase in global trade. RIFAs were primarily spread accidentally on transport vessels along with other goods involved in transnational trade (Ascunce et al. 2011). A political cause is improved governmental and interorganization relationships between countries in South America and the United States in the early 1900s that facilitated such trade by allowing for open exchange. A technological cause relates to advances in ship construction and operations around this same time that allowed for long distance transport of goods in unprecedented volumes. A cultural cause is the increasing preferences of consumers in the U.S. for foreign goods. A key ecological cause of the successful spread of the species is the innate superior competitive abilities of the species in the new environments into which it was introduced and their resilience to environmental challenges such as floods and droughts (Vinson 1997).

\section{Effects}

Effects refer to socioeconomic and environmental consequences or impacts of the telecoupling. They can be manifested in sending, receiving, and/or spillover systems in different ways (Fig. 2). Effects can occur at multiple spatial, temporal, and organizational scales. We divide effects into two main categories, socioeconomic and environmental (Table 1), but emphasize that the two are inherently linked to each other. These effects may promote or hinder environmental and/or socioeconomic sustainability (Liu 2010).

In the soybean example, trade between Brazil and China may cause increased intensity of agricultural land use in Brazil (Macedo et al. 2012), increased use of herbicides in no-tillage production systems, increased use of pesticides and fertilizers, mainly phosphorus, and loss of biodiversity and ecosystem services (Martinelli et al. 2010). Trade of soybeans has also caused displacement of local people and rural violence in Brazil, afforestation and carbon sequestration in China, and carbon emissions in spillover systems, e.g., throughout transport routes (Table 1). In China, many farmers have abandoned soybean production because of lower prices of soybean imported from Brazil and much of the original soybean land has been used for the production of other crops, e.g., maize, or converted into forests (GRAIN 2012). The trade has generated income for some sectors of Brazilian society (Lima et al. 2011). In the case of the RIFA invasion, species invasion has caused reduction of biodiversity in native invertebrate communities, destruction of habitat for wildlife, loss of agricultural crops and ensuing loss of income, damage to furniture and residences, and injury to livestock and humans as a result of painful and potentially dangerous bites from RIFA (Vinson 1997; Table 1).

Types of complex effects observed in individual coupled human and natural systems (Liu et al. 2007b) may also be evident in telecoupled systems, including indirect effects, sometimes called 'second-order effects,' cascading effects, nonlinearities, time lags, legacy effects, induced effects, and feedbacks. Cascading effects refer to phenomena in which the effects of telecoupling on one system or system component radiate outward to affect multiple other systems or components. In the soybean trade case, Embrapa in Brazil has taken its new agricultural technologies for soybean production to spillover countries in Africa where they are engaging in large-scale development in the savannas (Galerani and Bragantini 2007, Batistella and Bolfe 2010). Effects are often nonlinear, and may have time lags, in which they do not appear until years or even decades after the telecoupling is initiated. Legacy effects are those that may last for an extended period of time even after the telecoupling has ceased to operate. An example of an induced effect, i.e., a secondary effect brought on by another effect, in the soybean trade case is its influence on other agricultural sectors and overall consumer spending. Furthermore, changes in the income of laborers harvesting the soybeans cause labor income to vary, and create induced alterations in demand for food and other goods that the laborers consume, which has cascading effects on the broader economy and spillover systems (Altieri and Pengue 2005).

Feedbacks are important features of telecouplings. Feedbacks occur between systems when effects of the first system on a second system feed back to affect the first system. Some feedbacks between systems can be fast, while others may be very slow and take a long time to be realized or detected. In the soybean trade example, the shift in land use in China away from soybean production has led to a positive feedback, whereby China's demand for soybeans from Brazil has increased and resulted in further development of soybean production in Brazil. Furthermore, the soybean trade may also help promote more Chinese investment in Brazil and the import of products, e.g., machinery, textiles, from China to Brazil (Brainard and Welch 2012). In the RIFA invasion case, RIFA caused substantial environmental and socioeconomic damage to the receiving system, the U.S., prompting the development of techniques to hinder the spread of the invaders in the receiving system. The techniques then fed back to affect the sending system, South America. More specifically, between 1961 and 1975, 250,000 $\mathrm{kg}$ of the compound Mirex, a chlorinated hydrocarbon and derivative of cyclopentadiene, was used for ant control in the southeastern U.S. Nearly $150,000 \mathrm{~kg}$ was exported to Brazil for ant control during the same period (Eisler 2007). However, the use of Mirex had a 
double negative effect because (a) it is a bioacumlative pollutant and its use was prohibited by the U.S. Environmental Protection Agency in 1976, and (b) it helped to spread the fire ant because it also killed native ants that competed with the fire ants (Markin et al. 1974). Another feedback is the importation of natural enemies, e.g., flies and microorganisms, of the fire ant from Brazil to the U.S. as an invasion control method decades after the RIFA was established in the U.S. (Callcott et al. 2011).

Although some studies have been done regarding effects on both sending and receiving systems in each of our examples, little or no research has been published on their effects on spillover systems. Some research has shown transporting food and products can have huge impacts on the environment along and beyond the routes, such as energy consumption and emissions of pollutants, e.g., $\mathrm{CO}_{2}$. These suggest the potential impacts of transporting soybeans from Brazil to China, but no quantitative research on such impacts has been published.

There may be interactions among different types of telecouplings. For example, studies have found that the spread of many invasive species is made possible by trade (Westphal et al. 2008). Although no literature is available regarding the relationships between the two examples in this paper, applying the telecoupling framework may help researchers to look into possible relationships between soybean trade and species invasion, and their relations with other types of telecouplings.

\section{IMPLICATIONS OF THE TELECOUPLING FRAMEWORK}

The framework of telecoupling provides a common language, logical consistency, systematic approach, and holistic guidance for researchers and others who work on different types of distant interactions. It can help transform our understanding of how the world functions over distances and identify solutions to achieve socioeconomic and environmental sustainability across local to global levels, because it is uniquely integrative in several ways.

The framework integrates both socioeconomic and environmental interactions over distances, as opposed to just socioeconomic or environmental interactions

This can help expand the scope of previous research on distant interactions, such as trade, animal migration, climate teleconnections, which mainly focus on either socioeconomic interactions, e.g., trade, or environmental interactions, e.g., animal migration. Because it provides information on socioeconomic and environmental interactions simultaneously, it can help assess trade-offs between socioeconomic and environmental consequences, and achieve both socioeconomic and environmental sustainability, e.g., human well-being and biodiversity conservation (Carter et al. 2012, United Nations Environment Programme 2011).
The framework considers sending, receiving, and spillover systems together as a telecoupled and networked system, as opposed to just sending and/or receiving systems

By including spillover systems, the framework opens up a new frontier in research and policies because spillover systems were rarely considered before. For example, the framework suggests that bilateral agreements, which often focus on sending and receiving systems, should be adaptive by accounting for spillover systems as they emerge. In the soybean trade case, besides Brazil and China as soybean sending and receiving countries, spillover systems such as the U.S., a major soybean producer and a traditional exporter of soybean, are affected environmentally and socioeconomically because export of soybeans from Brazil to China affects China's import from the U.S.

The framework can help evaluate socioeconomic and environmental trade-offs and synergies across multiple systems, as opposed to just one system

For example, there have been calls for consuming local goods and products to support local producers and reduce environmental impacts from long distance transport (Halweil 2002). However, there have been measures that support the sustainability of distant systems, e.g., via purchasing sustainable coffee (Giovannucci and Ponte 2005). Still, others argue that dependence on local produce may compromise food security and forgo opportunities to use production areas with high yields and low environmental impacts (DesRochers and Shimizu 2012, MacMillan 2012). Indeed, the trade-offs between local and global sourcing of food are complex and system-dependent; for instance, recent evidence suggests that converting to local consumption may only reduce global emissions in regions with low intensity of greenhouse gas emissions (M. Avetisyan, T. W. Hertel, and G. Sampson, unpublished manuscript). Understanding synergies and tradeoffs of telecouplings can help minimize the negative externalities outside the system of prime interest.

The framework can help promote policies for sustainability because it explicitly considers distant interactions as feedbacks, as opposed to just unidirectional influence Feedbacks are an important mechanism to maintain system sustainability. Indeed, policies can be useful feedbacks to guide systems toward sustainability. By considering feedbacks explicitly, the framework can prompt researchers and policy makers to assess the existence and effectiveness of feedbacks among sending, receiving, and spillover systems. One example involves policies implemented to promote transnational land deals in developing countries, which initially bolster local economies, but later may promote social inequities and land degradation when positive feedbacks from foreign investment markets result in excessive use of local resources (Baird 2011). Thus, new policies should be developed to initiate negative feedbacks to reduce land degradation and social inequities. 
The framework can facilitate studies on the interrelationships among different types of distant interactions, as opposed to just one type of interaction Telecoupling is an umbrella concept and includes various distant interactions, e.g., trade, species invasion, migration (Linderman et al. 2005) and tourism (He et al. 2008; Table 2). Similar to the umbrella concept of ecosystem services, which encompasses a variety of nature's benefits to humans and facilitates studies on relationships among different types of services, e.g., carbon sequestration, food provisioning, pollination, water purification, and recreation (Daily 1997, Liu et al. 2008), the framework of telecoupling can help promote systematic, multidisciplinary studies on different types of distant interactions and their interrelationships. For example, it may promote cooperative research on trade and animal migration. Shade coffee plantations, which produce coffee for trade, have been known to provide key migratory bird habitat (Perfecto et al. 1996). At the same time, the presence of migratory birds on such plantations has promoted trade by creating a new market for trade of biodiversity friendly coffee to eco-conscious buyers (Rice and Ward 1996).

The telecoupling framework as presented here marks a significant conceptual advance by adding substantially to other related theoretical frameworks such as the Institutional Analysis and Development (IAD) framework of Elinor Ostrom and colleagues (Anderies et al. 2004, Ostrom 2005, 2011). IAD provides an analytical structure to understand how different institutions, i.e., formal rules and the rules-in-use, influence common and locally used resources. From a telecoupling perspective, some institutions may be understood as socioeconomic feedback mechanisms, using information on outcomes to adjust rules to accomplish societal goals. To this, the telecoupling framework adds a focus on biophysical feedbacks influencing the flows that move beyond the local systems in most IAD work. Furthermore, the telecoupling framework differs from the IAD framework by explicitly accounting for spillover systems and interactions, including feedbacks, among distant coupled systems that are increasingly interconnected (Liu and Diamond 2005, Henry and Dietz 2011).

Viewing distant interactions as telecouplings can help identify knowledge gaps and promote sustainability research and governance. The telecoupling framework expands traditional research on distant interactions to open new lines of inquiry and generate crucial insights on many otherwise hidden impacts. Although previous studies have largely focused on either socioeconomic issues of certain distant interactions, e. g. trade, foreign direct investment, technology transfer, human migration, or on environmental/ecological issues of other distant interactions, e.g., animal migration, they may all have both socioeconomic and environmental implications. There are many different types of telecouplings that can have profound effects on sustainability (Table 2).

\section{MOVING RESEARCH ON TELECOUPLING FORWARD}

Telecouplings offer unique challenges and opportunities for sustainability science and applications, e.g., conservation, development, provision of ecosystem services, climate change adaptation and mitigation, invasion control, energy use, land use, and water use. Many important and complex questions remain to be answered about telecouplings (Table 3). For instance, how do telecouplings emerge, how do they change over time, and how are they dissolved? How do they interact with each other? Under what conditions do telecouplings enhance or reduce sustainability? What properties of a given system make it more probable to become a sending, receiving, or spillover system for a given telecoupling? What are similarities and differences among telecouplings?

There are numerous knowledge gaps. For example, even though global trade is widely studied, many of its effects remain unknown. Although accounting for the land area necessary to produce traded agricultural products is useful (Meyfroidt et al. 2010), it does not measure many important environmental and socioeconomic effects because it does not consider the large differences among land-cover types in carbon stocks, biogeochemistry, and human well-being (Meyfroidt et al. 2010). Furthermore, in most studies, spillover systems have not been considered or recognized. However, effects of telecouplings on spillover systems may sometimes be even larger than those in receiving and sending systems. Spillover systems may play key roles in local to global sustainability because they connect and propagate the effects of telecouplings widely across space. In addition, crosssectoral connections among coupled systems remain a largely uninvestigated area of research. Examples include food-feedfuel exchanges in the agricultural sector and more broadly agriculture-energy-finance linkages among sending, receiving, and spillover systems, e.g., relationships between biofuels, financial investments, and land commodities.

Compared to local couplings, telecouplings create greater challenges for research (Table 3) and governance (Table 4) because they are more complex, involving multiple flows, multiple agents, multiple causes, and multiple effects across multiple systems at multiple scales and often across administrative and political borders. Governance approaches may need to be quite different between those depending on local couplings versus those in which telecouplings have strong influences. Systems that have only local couplings may lack resilience when disasters occur. Telecoupled systems may serve as reservoirs for replenishing populations of species depleted by disasters, and sources of information, material, and energy flows when local human infrastructure is destroyed. However, those who fully depend on telecouplings may also encounter risks when telecouplings dissolve or are disrupted and no substitutions are available. For example, when other countries' demands for products decline because 
Table 2. More examples of distant interactions as telecouplings and actual/hypothetical relationships to sustainability in sending, receiving, and spillover systems. Only some attributes of telecouplings have been studied in the past and most attributes remain unknown. Feedbacks among different systems are not stated for the sake of simplicity.

\section{Distant Interactions as Telecoupling \\ Trade of goods and products, e.g., food, timber, medicine, and minerals \\ Development investment, e.g., foreign direct investment}

Transnational land tenure transfer

Conservation investment

Technology transfer

Knowledge transfer

Human migration

Tourism

Waste transfer

Species invasion

Animal migration

Water transfer

Species dispersal

Atmospheric circulation

\section{Relationships to Sustainability in Sending, Receiving, and Spillover Systems}

Resources, e.g., land, water, labor, are used for producing goods and products in the sending systems, and pollutants are also released during the production processes. Socioeconomic sustainability may increase while environmental sustainability may be compromised. In receiving systems, environmental quality may increase while socioeconomic benefits, e.g., job loss, may suffer. In spillover systems, sustainability may be affected in various ways depending on the relationships with sending and receiving systems.

Development investment may stimulate economic markets and resource use, e.g., for agricultural production, manufacturing facilities, and affect the environment in the receiving systems, may or may not slow down economic growth or resource development in the sending systems, and may influence spillover systems in various ways. Transnational land tenure transfer, e.g., transnational land deals or land grabbing, may negatively affect land governance and tenure as well as livelihood of people and environment in sending systems, enhance food and energy security and improve environment in receiving systems, and affect spillover systems in various ways. Conservation investment, e.g., payments for ecosystem services, may conserve and restore environmental sustainability in receiving systems, may or may not compromise sustainability in the sending systems, and may influence spillover systems in various ways.

Technology generation may lead to socioeconomic and environmental consequences by consuming resources, e.g., land, water, energy, human resources, in sending systems. Technology implementation, e.g., new irrigation method, new vehicle battery, may affect environmental and socioeconomic sustainability in receiving and spillover systems. Knowledge transfer, e.g., theories, techniques, innovations, governance, and management approaches, may affect resource use patterns in receiving and spillover systems and can increase both environmental and socioeconomic sustainability, e.g., by increasing efficiency. The sending systems may benefit or suffer from knowledge transfer in terms of finance and recognitions.

Human migrants may or may not abandon the sending systems, e.g., land and other resources, and occupy the receiving systems, e.g., for jobs. The resource consumption also shifts from sending to receiving systems, influencing sustainability in both systems. Effects on sustainability in spillover systems may vary depending on their relationships with sending and receiving systems.

Tourism ventures, e.g., scenic spots, restaurants, hotels, and associated infrastructure, e.g., roads, may be undertaken in receiving and spillover systems and may bolster socioeconomic sustainability, but potentially threaten environmental sustainability. Sending systems may also be affected, e.g., by loss of financial capital to the receiving and spillover systems, by reducing resource consumption and benefitting the environment while absent at home. Transfer of waste, e.g., electronic waste and pollutants in the atmosphere and water, may reduce environmental and human health impacts in the sending systems, but may negatively affect sustainability in receiving and spillover systems by contaminating ecosystems, e.g., landfills, and affecting human health.

Invasive species occupy receiving and spillover systems, where they affect sustainability by altering land use and land cover, aquatic ecosystems, water quantity and quality, ecosystem services, economic revenues, and biodiversity. Sending systems may be affected through feedbacks from receiving and spillover systems, e.g., Mirex, a derivative of cyclopentadienem was exported from the U.S. (receiving system) to Brazil (sending system) to control the Red Imported Fire Ant that originated from South America such as Brazil.

Animal migrants, e.g., migratory birds, migratory ungulates, may use sending, receiving, and spillover systems during different times of the year. Migration affects ecosystem processes and environmental sustainability. Because migrants may spread diseases and predate on crops, they may also affect socioeconomic sustainability.

Facilities for water transfer, e.g., channels and reservoirs, may be created in sending, receiving, and spillover systems, and may change land use, water use, biodiversity, and economic growth in all systems. Water transfer increases water availability but spreads pollutants and invasive species to receiving and spillover systems, and reduces water in sending systems.

Species dispersal may result in a reduction in densities of animal, plant, or microbe species in the sending systems, but an increase in densities in the receiving and spillover systems, e.g., dispersal corridors. Changes in species densities may improve or harm environmental and socioeconomic sustainability in each system depending on their specific characteristics.

Circulation of atmosphere may affect environmental and socioeconomic sustainability in sending, receiving, and spillover systems. Examples include changes in water quantity and quality, e.g., through evaporation, land cover, e. g., soil erosion in sending systems and soil deposit in receiving systems, and ecosystem services, e.g., by transporting pollutants such as acid rain. of international competition, many manufacturing facilities in the U.S. have closed with devastating effects on local economies and human well-being (Minchin 2009). In systems where both local couplings and telecouplings already exist, it is important to evaluate how well they are balanced.
Integrating both local couplings and telecouplings into decision making can enhance adaptive capacity. Such integration may benefit from creating new institutions and/or reforming existing ones at the local, national, and international levels, e.g., the United Nations, World Bank, and World Trade 
Table 3. Example questions for further research on telecouplings and sustainability.

\begin{tabular}{|c|c|}
\hline \multicolumn{2}{|r|}{ Questions } \\
\hline \multicolumn{2}{|c|}{ Telecoupling components } \\
\hline Systems & $\begin{array}{l}\text { What properties of a given system make it more probable to become a sending, receiving, or spillover system for a given } \\
\text { telecoupling? How do spatial relationships between systems impact their status as sending, receiving, or spillover system and the } \\
\text { strength of the telecoupling? }\end{array}$ \\
\hline Flows & $\begin{array}{l}\text { How do telecoupling flows evolve over time and change across space? How do telecoupling flows interact (enhance and offset) } \\
\text { with each other? What are similarities and differences among different telecoupling flows? }\end{array}$ \\
\hline Agents & $\begin{array}{l}\text { How do agents change over time and across space? How do agents interact with each other? How do agents change their behavior } \\
\text { in response to telecoupling effects and dynamics? How do social networks form among agents and how are they maintained over } \\
\text { time? }\end{array}$ \\
\hline Causes & $\begin{array}{l}\text { What are major factors affecting telecoupling dynamics and intensity of the interactions? What is the relative importance of } \\
\text { various factors affecting the formation and dissolution of telecouplings? How do these factors interact and change over time? }\end{array}$ \\
\hline Effects & $\begin{array}{l}\text { How do telecouplings shape socioeconomic and environmental sustainability across local to global levels? What is the relative } \\
\text { importance of telecouplings versus local couplings for sustainability? What are the cascading effects of telecouplings on } \\
\text { sustainability? How are time lags and legacy effects produced? What are the feedbacks among sending, receiving, and spillover } \\
\text { systems? How do telecoupling effects alter resilience and vulnerability of telecoupled systems? }\end{array}$ \\
\hline \multicolumn{2}{|l|}{ Implications } \\
\hline For scientific research & $\begin{array}{l}\text { How do telecouplings emerge, evolve, and dissolve? How do telecouplings compromise or enhance sustainability in sending, } \\
\text { receiving, and spillover systems? Can sustainability be achieved in sending, receiving, and spillover systems simultaneously? } \\
\text { How do telecouplings vary across space and over time? How do telecouplings amplify or offset other forces behind sustainability? } \\
\text { Can the gain in one system be offset by another system? How can local and telecoupling forces work together? How can experts } \\
\text { in different disciplines collaborate to better understand complex telecoupled human and natural systems? How can the } \\
\text { sustainability science community advance telecoupling research effectively and efficiently? How can spillover systems be better } \\
\text { detected and accounted for in sustainability models? }\end{array}$ \\
\hline $\begin{array}{l}\text { For policy, } \\
\text { management, and } \\
\text { governance }\end{array}$ & $\begin{array}{l}\text { How can knowledge about telecouplings inform policy making and governance of sustainability from local to global levels? How } \\
\text { can institutions enhance positive effects of telecouplings and reduce negative effects of telecouplings for sustainability? How can } \\
\text { various coupled systems be managed and governed as a telecoupled system? What new policies are needed to effectively regulate } \\
\text { telecouplings for sustainability? }\end{array}$ \\
\hline
\end{tabular}

Organization. There have been some international policies that seek to manage for effects of distant interactions such as The Convention on International Trade in Endangered Species Flora and Fauna (CITES) and Reducing Emissions from Deforestation and Forest Degradation (REDD), both of which involve cross-country regulation of flows of materials that affect sustainability, i.e., endangered species, carbon, and forest products. However these endeavors often focus on particular socioeconomic or environmental impacts and few attempt to approach policy making from an integrated telecoupling perspective, a perspective that addresses multiple impacts and feedbacks among sending, receiving, and spillover systems.

Priorities for advancing telecoupling research include: (1) development and integration of new theories and methods to better examine telecouplings for sustainability, e.g., how feedbacks influence multisystem dynamics, (2) creation of knowledge on telecouplings and insights useful for assessing changes in telecoupled systems, e.g., how trade in commodities influences people and the environment in sending, receiving, and spillover systems, (3) exploration of complex relationships among various telecouplings, e.g., species invasions, trade, migration, disease spread, flows of ecosystem services, and (4) investigation of strategies for making telecoupled systems more sustainable at multiple scales and across different systems.
Studying and promoting sustainability in the context of telecouplings requires new research directions. These may include (1) adoption of the telecoupling framework, (2) changes in research approaches from locally focused inquiry to network-based inquiry into telecoupled systems, e.g., expansion of research at individual places to connections among multiple places, and from multisite comparisons to cross-system integration, and (3) collaborations among researchers and stakeholders in sending, receiving, and spillover systems. Network science may provide especially useful theoretical and methodological tools for understanding telecoupled systems, which are fundamentally a form of networks (Bodin and Prell 2011). Studying telecouplings can fill many research gaps such as determining ecological consequences of increased social networking for distant resource usage, and predicting future land and water use scenarios to address global land and water shortages for food and biofuel production.

The telecoupling framework can also lead to new analytical approaches and improve existing approaches. For example, agent-based modeling is widely used for research in land change and coupled human and natural systems (Chen et al. 2012; Filatova et al., in press), but the agents are mainly restricted to those within a coupled human and natural system. The telecoupling framework calls for explicitly incorporating interactions among agents in distant coupled systems, or 
Table 4. Differences between local couplings and telecouplings.

\begin{tabular}{lcc}
\hline \hline & Local Couplings & Telecouplings \\
\hline Number of coupled human and natural systems & One & Two or more \\
Flows, agents, causes, and effects & Local & Local and distant \\
Alternative livelihood options beyond local resources & No & Yes \\
Risk of relying on local resources & High & Low \\
Complexity of management and governance & Low & High \\
\hline
\end{tabular}

telecoupled agents, in shaping land change and dynamics of coupled systems. Similarly, scenario analysis and forecasting have mainly considered components and interactions within a coupled system (Millennium Ecosystem Assessment 2005, Moss et al. 2010). A telecoupling perspective can help develop more realistic scenarios and more accurate forecasting to reflect an increasingly telecoupled world.

Systems integration, or bringing together data on different aspects of the telecoupled system from diverse disciplines, can help understand telecouplings. For example, systems models can be employed to explore the long-term consequences of policy scenarios regarding telecouplings to enhance their positive effects and reduce their negative effects across multiple scales, and evaluate sustainability options for adaptation to changes in telecouplings. Studies at the global and national scales can provide a broad context of telecouplings, while studies at regional and local scales can achieve detailed understanding of coupled systems, flows, agents, causes, and effects of telecouplings in particular systems. For example, although there have been studies at the international level on displacement of land use (Meyfroidt et al. 2010, Lambin and Meyfroidt 2011), especially deforestation (DeFries et al. 2010), few studies at the national, regional, and local scales have been simultaneously linked to global-scale analyses (Rudel 2005, Rudel et al. 2005, DeFries et al. 2010). By taking a multiscale systems approach, it is possible to trace telecouplings. Studies on telecouplings can also benefit from a portfolio approach (Young et al. 2006), which involves developing a multidisciplinary toolbox of theories and approaches, because no single method is able to accomplish everything (Verburg et al. 2008). Furthermore, revolutionary communication technologies such as social networking tools could enable the establishment of "crowdsourcing" platforms (van der Velde et al. 2012) and more participatory and transparent approaches to research and governance for positive socioeconomic and environmental outcomes.

\section{CONCLUSIONS}

The telecoupling framework provides a broader analytical lens to integrate distant socioeconomic and environmental interactions affecting sustainability across local to global levels. It explicitly accounts for environmental and socioeconomic interactions across sending, receiving, and spillover systems simultaneously. As a common and logically consistent language, the framework integrates various human and natural elements, e.g., land, water, climate, energy, air, humans, and organisms, involved in a variety of distant interactions, e.g., trade, species invasion, disease spread, flows of ecosystem services. It provides a useful means to incorporate interconnections and feedbacks as well as socioeconomic and environmental benefits and costs, as called for in the recent reports of the United Nations SecretaryGeneral's High-level Panel on Global Sustainability (2012) and the International Council for Science (2010). It can also help identify new insights that cannot be obtained from considering one type of distant interaction alone, because many telecouplings may have complex interrelationships. Understanding telecoupling has important implications for governing global sustainability in an increasingly telecoupled world.

Responses to this article can be read online at: http://www.ecologyandsociety.org/issues/responses. $\mathrm{php} / 5873$

\section{Acknowledgments:}

We thank the National Science Foundation, Michigan State University, U.S. DOE Office of Science, and Michigan AgBioResearch for funding. We are also grateful to Anthony Janetos, Harini Nagendra, Phil Robertson, and Robert Walker for helpful input.

\section{LITERATURE CITED}

Adger, W. N., H. Eakin, and A. Winkels. 2009. Nested and teleconnected vulnerabilities to environmental change. Frontiers in Ecology and the Environment 7:150-157.

Aker, J. 2008. Does digital divide or provide? The impact of cell phones on grain markets in Niger. Working Paper 154, Center for Global Development, Washington, D.C., USA. http://dx.doi.org/10.2139/ssrn.1093374

Alberti, M., H. Asbjornsen, L. A. Baker, N. Brozovic, L. E. Drinkwater, S. A. Drzyzga, C. A. Jantz, J. Fragoso, D. S. Holland, T. A. Kohler, J. Liu, W. J. McConnell, H. D. G. 
Maschner, J. D. A. Millington, M. Monticino, G. Podestá, R. G. Pontius Jr., C. L. Redman, N. J. Reo, D. Sailor, and G. Urquhart. 2011. Research on coupled human and natural systems (CHANS): approach, challenges, and strategies. Bulletin of the Ecological Society of America 92:218-228. http://dx.doi.org/10.1890/0012-9623-92.2.218

Altieri, M. A., and W. A. Pengue. 2005. Roundup ready soybean in Latin America: a machine of hunger, deforestation and socio-ecological devastation. RAP-AL, Montevideo, Uruguay. [online] URL: http://webs.chasque.net/ rapaluy1/ transgenicos/Prensa/Roundupready.html

Alves, B. J. R., R. M. Boddey, and S. Urquiaga. 2003. The success of BNF in soybean in Brazil. Plant and Soil 252:1-9. http://dx.doi.org/10.1023/A:1024191913296

Alves, B. J. R., L. Zotarelli, F. M. Fernandes, J. C. Heckler, R. A. T. Macedo, R. M. Boddey, C. P. Jantalia, and S. Urquiaga. 2006. Biological nitrogen fixation and nitrogen fertilizer on the nitrogen balance of soybean, maize and cotton. [Title translated from Portugese.] Pesquisa Agropecuária Brasileira 41:449-456. http://dx.doi.org/10.1590/ S0100-204X2006000300011

Anderies, J. M., M. A. Janssen, and E. Ostrom. 2004. A framework to analyze the robustness of social-ecological systems from an institutional perspective. Ecology and Society 9(1): 18. [online] URL: http://www.ecologyandsociety.org/ vol9/iss $1 / \operatorname{art} 18 /$

Ascunce, M. S., C.-C. Yang, J. Oakey, L. Calcaterra, W.-J. Wu, C.-J. Shih, J. Goudet, K. G. Ross, and D. Shoemaker. 2011. Global invasion history of the fire ant Solenopsis invicta. Science 331:1066-1068. http://dx.doi.org/10.1126/science.1198734

Baird, I. G. 2011. Turning land into capital, turning people into labour: primitive accumulation and the arrival of largescale economic land concessions in the Lao People's Demogratic Republic. New Proposals: Journal of Marxism and Interdisciplinary Inquiry 5:10-26.

Banse, M., H. van Meijl, A. Tabeau, and G. Woltjer. 2008. Will EU biofuel policies affect global agricultural markets? European Review of Agricultural Economics 35:117-141. http://dx.doi.org/10.1093/erae/jbn023

Batistella, M., and E. L. Bolfe. 2010. Elos de Cooperação. Pages 9-12 in M. Batistella and E. L. Bolfe, editors. Paralelos: Corredor de Nacala. v. 1. Embrapa Monitoramento por Satélite, Campinas, São Paulo, Brazil. [online] URL: http:// www.cnpm.embrapa.br/projetos/mocambique/download/ ebook_paralelos/Livro_Paralelos.html

Bodin, Ö., and C. Prell. 2011. Social networks and natural resource management: uncovering the social fabric of environmental governance. Cambridge University Press, Cambridge, UK. http://dx.doi.org/10.1017/CBO9780511894985
Brainard, L., and J. H. Welch. 2012. Brazil and China: clouds on the horizon. America's Quarterly, 24 January. [online URL: http://www.americasquarterly.org/node/3255

Brown-Lima, C., M. Cooney, and D. Cleary. 2010. An overview of the Brazil-China soybean trade and its strategic implications for conservation. The Nature Conservancy, Washington, D.C., USA.

Callaway, R. M., and W. M. Ridenour. 2004. Novel weapons: invasive success and the evolution of increased competitive ability. Frontiers in Ecology and the Environment 2:436-443. http://dx.doi.org/10.1890/1540-9295(2004)002[0436:NWISAT] 2.0.CO;2

Callcott, A. M. A., S. D. Porter, R. D. Weeks, L. C. Graham, S. J. Johnson, and L. E. Gilbert. 2011. Fire ant decapitating fly cooperative release programs (1994-2008): two Pseudacteon species, P. tricuspis and P. curvatus, rapidly expand across imported fire ant populations in the southeastern United States. Journal of Insect Science 11(19):1-25. http:// dx.doi.org/10.1673/031.011.0119

Carter, N. H., B. K. Shrestha, J. B. Karki, N. M. B. Pradhan, and J. Liu. 2012. Coexistence between wildlife and humans at fine spatial scales. Proceedings of the National Academy of Sciences of the United States of America 109:15360-15365.

Chen, X., F. Lupi, L. An, R. Sheely, A. Vina, and J. G. Liu. 2012. Agent-based modeling of the effects of social norms on enrollment in payments for ecosystem services. Ecological Modelling 229:16-24. http://dx.doi.org/10.1016/j.

ecolmodel.2011.06.007

Crosby, A. W. 1986. Ecological imperialism: the biological expansion of Europe, 900-1900. Cambridge University Press, UK.

Daily, G., editor. 1997. Nature's services: societal dependence on natural ecosystems. Island Press, Washington, D.C., USA.

DeFries, R. S., T. Rudel, M. Uriarte, and M. Hansen. 2010. Deforestation driven by urban population growth and agricultural trade in the twenty-first century. Nature Geoscience 3:178-181. http://dx.doi.org/10.1038/ngeo756

DesRochers, P., and H. Shimizu. 2012. The locavore's dilemma: in praise of the 10,000-mile diet. PublicAffairs, New York, New York, USA.

Dreher, A., N. Gaston, and P. Martens. 2008. Measuring globalisation: gauging its consequences. Springer, New York, New York, USA. http://dx.doi.org/10.1007/978-0-387-74069-0

Eakin, H., A. Winkels, and J. Sendzimir. 2009. Nested vulnerability: exploring cross-scale linkages and vulnerability teleconnections in Mexican and Vietnamese coffee systems. Environmental Science \& Policy 12:398-412. http://dx.doi. org/10.1016/j.envsci.2008.09.003 
Eisler, R. 2007. Eisler's encyclopedia of environmentally hazardous priority chemicals. Elsevier Science, Amsterdam. The Netherlands.

Feng, H., and B. A. Babcock. 2010. Impacts of ethanol on planted acreage in market equilibrium. American Journal of Agricultural Economics 92:789-802. http://dx.doi.org/10.1093/ ajae/aaq023

Filatova, T., P. H. Verburg, D. C. Parker, and C. A. Stannard. In press. Spatial agent-based models for socio-ecological systems: challenges and prospects. Environmental Modelling \& Software. [online] URL: http://www.sciencedirect.com/ science/article/pii/S1364815213000807

Galerani, P. R., and C. Bragantini. 2007. Transfer of tropical agricultural technologies from Brazil to African Countries. Pages 1391-1398 in African Crop Science Conference Proceedings. African Crop Science Society, El-Minia, Egypt.

Giovannucci, D., and S. Ponte. 2005. Standards as a new form of social contract? Sustainability initiatives in the coffee industry. Food Policy 30:284-301. http://dx.doi.org/10.1016/ j.foodpol.2005.05.007

Glantz, M. H., R. W. Katz, and N. Nicholls. 1991. Teleconnections linking worldwide climate anomalies. Cambridge University Press, Cambridge, UK.

GRAIN. 2012. Who will feed China: agribusiness or its own farmers? Decisions in Beijing echo around the world. GRAIN, Barcelona, Spain. [online] URL: http://www.grain.org/article/ entries/4546-who-will-feed-china-agribusiness-or-its-own-farmersdecisions-in-beijing-echo-around-the-world

Haas, P. M. 1993. Epistemic communities and the dynamics of international environmental cooperation. Pages 168-201 in V. Rittberger and P. Mayer, editors. Regime theory and international relations. Oxford University Press, New York, New York, USA.

Halweil, B. 2002. Home grown: the case for local food in a global market. Worldwatch Institute, Washington, D.C., USA.

He, G., X. Chen, W. Liu, S. Bearer, S. Zhou, L. Y. Cheng, H. Zhang, Z. Ouyang, and J. Liu. 2008. Distribution of economic benefits from ecotourism: a case study of Wolong Nature Reserve for giant pandas in China. Environmental Management 42:1017-1025. http://dx.doi.org/10.1007/ s00267-008-9214-3

Henry, A. D., and T. Dietz. 2011. Information, networks, and the complexity of trust in commons governance. International Journal of the Commons 5:188-212.

Hertel, T. W., and T. Mirza. 2009. The role of trade facilitation in South Asian economic integration. Pages 12-39 in Study on intraregional trade and investment in South Asia. The Asian Development Bank, Manila, Philippines.
Horan, R. D., and F. Lupi. 2005. Tradeable risk permits to prevent future introductions of invasive alien species into the Great Lakes. Ecological Economics 52:289-304. http://dx.doi. org/10.1016/j.ecolecon.2004.06.018

Hornborg, A., J. R. McNeill, and J. M. Alier. 2007. Rethinking environmental history: world-system history and global environmental change. Altamira Press, Walnut Creek, California, USA.

International Council for Science. 2010. Earth system science for global sustainability: the grand challenges. International Council for Science, Paris, France.

Jackson, M. O., and A. Watts. 2002. The evolution of social and economic networks. Journal of Economic Theory 106:265-295. http://dx.doi.org/10.1006/jeth.2001.2903

Jones, P. G., and P. K. Thornton. 2003. The potential impacts of climate change on maize production in Africa and Latin America in 2055. Global Environmental Change 13:51-59. http://dx.doi.org/10.1016/S0959-3780(02)00090-0

Kastner, T., K.-H. Erb, and S. Nonhebel. 2011. International wood trade and forest change: a global analysis. Global Environmental Change 21:947-956. http://dx.doi.org/10.1016/ j.gloenvcha.2011.05.003

Kates, R. W., W. C. Clark, R. Corell, J. M. Hall, C. C. Jaeger, I. Lowe, J. J. McCarthy, H. J. Schellnhuber, B. Bolin, N. M. Dickson, S. Faucheux, G. C. Gallopin, A. Grübler, B. Huntley, J. Jäger, N. S. Jodha, R. E. Kasperson, A. Mabogunje, P. Matson, H. Mooney, B. Moore III, T. O'Riordan, and U. Svedin. 2001. Sustainability science. Science 292:641-642. http://dx.doi.org/10.1126/science.1059386

Konar, M., C. Dalin, S. Suweis, N. Hanasaki, A. Rinaldo, and I. Rodriguez-Iturbe. 2011. Water for food: the global virtual water trade network. Water Resources Research 47:W05520. http://dx.doi.org/10.1029/2010WR010307

Laland, K. N., K. Sterelny, J. Odling-Smee, W. Hoppitt, and T. Uller. 2011. Cause and effect in biology revisited: is Mayr's proximate-ultimate dichotomy still useful? Science 334:1512-1516. http://dx.doi.org/10.1126/science.1210879

Lambin, E. F., and P. Meyfroidt. 2011. Global land use change, economic globalization, and the looming land scarcity. Proceedings of the National Academy of Sciences of the United States of America 108:3465-3472. http://dx.doi.org/10.1073/ pnas. 1100480108

Lenzen, M., D. Moran, K. Kanemoto, B. Foran, L. Lobefaro, and A. Geschke. 2012. International trade drives biodiversity threats in developing nations. Nature 486:109-112. http://dx. doi.org/10.1038/nature 11145

Levitt, T. 1983. The globalization of markets. Harvard Business Review 61:92-102. 
Li, Q., and R. Reuveny. 2003. Economic globalization and democracy: an empirical analysis. British Journal of Political Science 33:29-54. http://dx.doi.org/10.1017/S0007123403000024

Lima, M., M. Skutsch, and G. de Medeiros Costa. 2011. Deforestation and the social impacts of soy for biodiesel: perspectives of farmers in the South Brazilian Amazon. Ecology and Society 16(4): 4. http://dx.doi.org/10.5751/ ES-04366-160404

Linderman, M. A., L. An, S. Bearer, G. He, Z. Ouyang, and J. Liu. 2005. Modeling the spatio-temporal dynamics and interactions of households, landscapes, and giant panda habitat. Ecological Modelling 183:47-65. http://dx.doi. org/10.1016/j.ecolmodel.2004.07.026

Liu, J. 2010. China's road to sustainability. Science 328:50. http://dx.doi.org/10.1126/science.1186234

Liu, J., and J. Diamond. 2005. China's environment in a globalizing world. Nature 435:1179-1186. http://dx.doi. org $/ 10.1038 / 4351179$ a

Liu, J., T. Dietz, S. R. Carpenter, M. Alberti, C. Folke, E. Moran, A. N. Pell, P. Deadman, T. Kratz, J. Lubchenco, E. Ostrom, Z. Ouyang, W. Provencher, C. L. Redman, S. H. Schneider, and W. W. Taylor. 2007b. Complexity of coupled human and natural systems. Science 317:1513-1516. http://dx. doi.org/10.1126/science.1144004

Liu, J., T. Dietz, S. R. Carpenter, C. Folke, M. Alberti, C. L. Redman, S. H. Schneider, E. Ostrom, A. N. Pell, J. Lubchenco, W. W. Taylor, Z. Ouyang, P. Deadman, T. Kratz, and W. Provencher. 2007a. Coupled human and natural systems. AMBIO: A Journal of the Human Environment 36:639-649.

Liu, J., S. Li, Z. Ouyang, C. Tam, and X. Chen. 2008. Ecological and socioeconomic effects of China's policies for ecosystem services. Proceedings of the National Academy of Sciences of the United States of America 105:9477-9482. http://dx.doi.org/10.1073/pnas.0706436105

Liu, J., W. McConnell, and T. Baerwald, organizers. 2011. Symposium on "Telecoupling of Human and Natural Systems" at the meeting of the American Association for the Advancement of Science. [online] URL: http://aaas.confex. com/aaas/2011/webprogram/Session2889.html

Liu, J., and W. Yang. 2012. Water sustainability for China and beyond. Science 337:649-650. http://dx.doi.org/10.1126/ science. 1219471

Lowe, S., M. Browne, S. Boudjelas, and M. D. Poorter. 2000. 100 of the world's worst invasive alien species: a selection from the Global Invasive Species Database. Invasive Species Specialist Group (ISSG), Species Survival Commission (SSC) of the World Conservation Union (IUCN), Aukland, New Zealand. [online] URL: http://www.issg.org/database/ species/reference files/100English.pdf
Macedo, M. N., R. S. DeFries, D. C. Morton, C. M. Stickler, G. L. Galford, and Y. E. Shimabukuro. 2012. Decoupling of deforestation and soy production in the southern Amazon during the late 2000s. Proceedings of the National Academy of Sciences of the United States of America 109:1341-1346. http://dx.doi.org/10.1073/pnas.1111374109

MacMillan, T. 2012. Food security: eating globally. Nature 486:30-31. http://dx.doi.org/10.1038/486030a

Margolis, M., J. F. Shogren, and C. Fischer. 2005. How trade politics affect invasive species control. Ecological Economics 52:305-313. http://dx.doi.org/10.1016/j.ecolecon.2004.07.017

Markin, G. P., J. Oneal, and H. Collins. 1974. Effects of mirex on the general ant fauna of a treated area in Louisiana. Environmental Entomology 3:895-898.

Martinelli, L. A., R. Naylor, P. M. Vitousek, and P. Moutinho. 2010. Agriculture in Brazil: impacts, costs, and opportunities for a sustainable future. Current Opinion in Environmental Sustainability 2:431-438. http://dx.doi.org/10.1016/j. cosust.2010.09.008

Meyfroidt, P., T. K. Rudel, and E. F. Lambin. 2010. Forest transitions, trade, and the global displacement of land use. Proceedings of the National Academy of Sciences of the United States of America 107:20917-20922. http://dx.doi.org/10.1073/ pnas. 1014773107

Millennium Ecosystem Assessment. 2005. Ecosystems and human well-being: biodiversity synthesis. World Resources Institute, Washington, D.C., USA.

Milstien, J. B., M. Kaddar, and M. P. Kieny. 2006. The impact of globalization on vaccine development and availability. Health Affairs 25:1061-1069. http://dx.doi.org/10.1377/ hlthaff.25.4.1061

Minchin, T. J. 2009. 'It knocked this city to its knees': the closure of Pillowtex Mills in Kannapolis, North Carolina and the decline of the US textile industry. Labor History 50:287-311. http://dx.doi.org/10.1080/00236560903020906

Moran, E. F. 2010. Environmental social science: humanenvironment interactions and sustainability. WileyBlackwell, Hoboken, New Jersey, USA.

Moss, R. H., J. A. Edmonds, K. A. Hibbard, M. R. Manning, S. K. Rose, D. P. van Vuuren, T. R. Carter, S. Emori, M. Kainuma, T. Kram, G. A. Meehl, J. F. B. Mitchell, N. Nakicenovic, K. Riahi, S. J. Smith, R. J. Stouffer, A. M. Thomson, J. P. Weyant, and T. J. Wilbanks. 2010. The next generation of scenarios for climate change research and assessment. Nature 463:747-756. http://dx.doi.org/10.1038/ $\underline{\text { nature } 08823}$ 
National Research Council. 2012. Ecosystem services: charting a path to sustainability. National Academies, Washington, D.C., USA.

National Science Foundation Advisory Committee for Environmental Research and Education. 2009. Transitions and tipping points in complex environmental systems: a report. National Science Foundation, Arlington, Virginia, USA.

Nelson, G. C. 2005. Drivers of ecosystem change: summary chapter. Pages 73-76 in R. Hassan, R. Scholes, and N. Ash, editors. Ecosystems and human well-being: current state and trends. Island Press, Washington, D.C. USA.

Nentwig, W. 2007. Pathways in animal invasions. Pages 11-27 in W. Nentwig, editor. Biological invasions. Springer, Berlin, Germany. http://dx.doi.org/10.1007/978-3-540-36920-2_2

Niu, H. 2010. Emerging global partnership: Brazil and China. Revista Brasileira De Política Internacional 53:183-192. http://dx.doi.org/10.1590/S0034-73292010000300011

Ostrom, E. 2005. Understanding institutional diversity. Princeton University Press, Princeton, New Jersey, USA.

Ostrom, E. 2011. Background on the institutional analysis and development framework. Policy Studies Journal 39:7-27. http://dx.doi.org/10.1111/j.1541-0072.2010.00394.x

Perfecto, I., R. A. Rice, R. Greenberg, and M. E. Van der Voort. 1996. Shade coffee: a disappearing refuge for biodiversity. BioScience 46:598-608. http://dx.doi.

org/10.2307/1312989

Reid, W. V., D. Chen, L. Goldfarb, H. Hackmann, Y. T. Lee, K. Mokhele, E. Ostrom, K. Raivio, J. Rockström, H. Schellnhuber, and A. Whyte. 2010. Earth system science for global sustainability: grand challenges. Science 330:916-917. http://dx.doi.org/10.1126/science.1196263

Rice, R. A. and J. Ward. 1996. Coffee, conservation, and commerce in the western hemisphere: how individuals and institutions can promote ecologically sound farming and forest management in northern Latin America. Smithsonian Migratory Bird Center, Washington, D.C., USA.

Rudel, T. K. 2005. Tropical forests: regional paths of destruction and regeneration in the late twentieth century. Columbia University Press, New York, New York, USA.

Rudel, T. K., O. T. Coomes, E. Moran, F. Achard, A. Angelsen, J. $\mathrm{Xu}$, and E. Lambin. 2005. Forest transitions: towards a global understanding of land use change. Global Environmental Change 15:23-31. http://dx.doi.org/10.1016/j. gloenvcha.2004.11.001

Rudel, T. K., L. Schneider, M. Uriarte, B. L. Turner II, R. DeFries, D. Lawrence, J. Geoghegan, S. Hecht, A. Ickowitz, E. F. Lambin, T. Birkenholtz, S. Baptista, and R. Grau. 2009.
Agricultural intensification and changes in cultivated areas, 1970-2005. Proceedings of the National Academy of Sciences of the United States of America 106:20675-20680. http://dx. doi.org/10.1073/pnas.0812540106

Seto, K. C., A. Reenberg, C. G. Boone, M. Fragkias, D. Haase, T. Langanke, P. Marcotullio, D. K. Munroe, B. Olah, and D. Simon. 2012. Urban land teleconnections and sustainability. Proceedings of the National Academy of Sciences of the United States of America 109:7687-7692. http://dx.doi.org/10.1073/ pnas.1117622109

Swinton, S. M., B. A. Babcock, L. K. James, and V. Bandaru. 2011. Higher US crop prices trigger little area expansion so marginal land for biofuel crops is limited. Energy Policy 39:5254-5258. http://dx.doi.org/10.1016/i.enpol.2011.05.039

Turner, B. L., II, R. E. Kasperson, P. A. Matson, J. J. McCarthy, R. W. Corell, L. Christensen, N. Eckley, J. X. Kasperson, A. Luers, M. L. Martello, C. Polsky, A. Pulsipher, and A. Schiller. 2003. A framework for vulnerability analysis in sustainability science. Proceedings of the National Academy of Sciences of the United States of America 100:8074-8079. http://dx.doi. org/10.1073/pnas.1231335100

United Nations Department of Economic and Social Affairs. 2012. World urbanization prospects: the 2011 revision. United Nations, New York, New York, USA. [online] URL: http:// esa.un.org/unup/CD-ROM/Urban-Rural-Population.htm

United Nations Environment Programme. 2011. Towards a green economy: pathways to sustainable development and poverty eradication. United Nations Environment Programme, Nairobi, Kenya. [online] URL: http://www.unep.org/ greeneconomy/Portals/88/documents/ger/ger final dec 2011/ Green\%20EconomyReport_Final_Dec2011.pdf

United Nations Secretary-General's High-level Panel on Global Sustainability. 2012. Resilient people, resilient planet: a future worth choosing. United Nations, New York, New York, USA.

United Nations Statistics Division. 2012. UNcomtrade: United Nations Commodity Trade Statistics Database. Statistics Division, United Nations, New York, New York, USA. [online] URL: http://comtrade.un.org/db

United States Department of Agriculture Foreign Agricultural Service. 2010. Production, supply and distribution online (PSD). Unites States Department of Agriculture, Washington, D.C., USA. [online] URL: http://www.fas.usda.gov/ psdonline

Vander Meer, R. K., T. Slowik, and H. Thorvilson. 2002. Semiochemicals released by electrically stimulated red imported fire ants, Solenopsis invicta. Journal of Chemical Ecology 28:2585-2600. http://dx.doi.org/10.1023/A:1021448522147 
van der Velde, M., L. See, and S. Fritz. 2012. Conservation: citizens add to satellite forest maps. Nature 490:342. http:// dx.doi.org/10.1038/490342a

Van Kooten, G. C., H. W. Nelson, and I. Vertinsky. 2005. Certification of sustainable forest management practices: a global perspective on why countries certify. Forest Policy and Economics 7:857-867. http://dx.doi.org/10.1016/j.forpol.2004.04.003

Verburg, P. H., B. Eickhout, and H. van Meijl. 2008. A multiscale, multi-model approach for analyzing the future dynamics of European land use. Annals of Regional Science 42:57-77. http://dx.doi.org/10.1007/s00168-007-0136-4

Vinson, S. 1997. Invasion of the red imported fire ant (Hymenoptera: Formicidae): spread, biology, and impact. American Entomologist 43:23-39.

Walker, B., C. S. Holling, S. R. Carpenter, and A. Kinzig. 2004. Resilience, adaptability and transformability in socialecological systems. Ecology and Society 9(2): 5. [online] URL: http://www.ecologyandsociety.org/vol9/iss2/art5/

Westphal, M. I., M. Browne, K. MacKinnon, and I. Noble. 2008. The link between international trade and the global distribution of invasive alien species. Biological Invasions 10:391-398. http://dx.doi.org/10.1007/s10530-007-9138-5

Young, O. R., E. F. Lambin, F. Alcock, H. Haberl, S. I. Karlsson, W. J. McConnell, T. Myint, C. Pahl-Wostl, C. Polsky, P. S. Ramakrishnan, H. Schroeder, M. Scouvart, and P. H. Verburg. 2006. A portfolio approach to analyzing complex human-environment interactions: institutions and land change. Ecology and Society 11(2): 31. [online] URL: http://www.ecologyandsociety.org/vol11/iss2/art31/

Zhang, Z., and Z. Liu. 2009. China's soybean demand and supply: current situation and projection for the next 10 years. Soybean Science and Technology 2009:16-21. [Titles translated from Chinese.]

Zhu, C., and G. Feng. 2003. Case studies of policies and management of the green for grain programme in China. [Title translated from Chinese.] Science Press, Beijing, China.

Zhu, C., R. Taylor, and G. Feng. 2004. China's wood market, trade and the environment. Science Press USA, Monmouth Junction, New Jersey, USA. 
Appendix 1.

\begin{tabular}{|c|c|}
\hline $\begin{array}{l}\text { Distant } \\
\text { interactions }\end{array}$ & Trends \\
\hline $\begin{array}{l}\text { Trade of goods } \\
\text { and products }\end{array}$ & $\begin{array}{l}\text { Global agricultural exports have increased from about } 3.5 \text { billion USD in } \\
1961-63 \text { to about } 110 \text { billion USD in } 2009 \text { (FAO 2012) }\end{array}$ \\
\hline $\begin{array}{l}\text { Development } \\
\text { investment }\end{array}$ & $\begin{array}{l}\text { Global Foreign Direct Investment (FDI) flows rose from } 400 \text { billion USD } \\
\text { in } 1995 \text { to over 1,500 billion USD in } 2011 \text { (UNCTAD 2012). }\end{array}$ \\
\hline $\begin{array}{l}\text { Transnational } \\
\text { land tenure } \\
\text { transfer }\end{array}$ & $\begin{array}{l}\text { Between } 2000 \text { and } 2009 \text {, the amount of land involved in transnational land } \\
\text { deals each year increased from } 3 \text { million hectares to approximately } 30 \\
\text { million hectares (Anseeuw et al. 2012). Land deals subsequently declined } \\
\text { in } 2010 \text { to roughly } 8 \text { million hectares (Anseeuw et al. 2012). }\end{array}$ \\
\hline $\begin{array}{l}\text { Conservation } \\
\text { investment }\end{array}$ & $\begin{array}{l}\text { Bilateral flows of Overseas Development Assistance (ODA) for forest } \\
\text { conservation went from 600-900 million USD in the late 1980s to more } \\
\text { than } 1 \text { billion USD in 1990-92 before declining to the previous amount by } \\
\text { the late 1990s (Molnar et al. 2004). Multilateral flows were 500-700 } \\
\text { million USD in the late 1980s, over } 1 \text { billion USD in 1990-92, and below } \\
400 \text { million USD in the mid 1990s (Molnar et al. 2004). Total ODA } \\
\text { funding for forest conservation in the period of 2005-2007 was similar at } \\
700 \text { million USD (Lawlor and Olander 2009). }\end{array}$ \\
\hline $\begin{array}{l}\text { Hum } \\
\text { migr }\end{array}$ & $\begin{array}{l}\text { Cities gain an estimated } 60 \text { million people per year - over } 1 \text { million every } \\
\text { week. In many developing countries, populations in cities are growing two } \\
\text { or three times faster than the total population. About } 5 \text { billion people are } \\
\text { predicted to live in cities by } 2030 \text { ( } 61 \% \text { of the global population) } \\
\text { (Hinrichsen 2010). Most of the population increases are due to rural-urban } \\
\text { migration. }\end{array}$ \\
\hline Tourism & $\begin{array}{l}\text { The number of global international tourists increased from under } 100 \\
\text { million in } 1960 \text { to over } 900 \text { million in } 2005 \text { (World Tourism Organization } \\
\text { 2009). }\end{array}$ \\
\hline Waste transfer & $\begin{array}{l}\text { The U.S. exports of waste increased from } 5 \text { billion USD in } 2000 \text { to over } 30 \\
\text { billion USD in } 2011 \text { (Editorial Code and Data Inc. 2012). }\end{array}$ \\
\hline $\begin{array}{l}\text { Species } \\
\text { invasion }\end{array}$ & $\begin{array}{l}\text { The number of introduced species per year in Europe jumped by } 300 \% \text { for } \\
\text { plant species and } 600 \% \text { for invertebrates and mammals between } 1800- \\
1850 \text { and } 1975-2000 \text { (Hulme 2009). }\end{array}$ \\
\hline Transportation & $\begin{array}{l}\text { Air freight travel worldwide has nearly doubled from } 1990 \text { to } 2004 \\
\text { (European Environment Agency 2007). }\end{array}$ \\
\hline
\end{tabular}




\section{References}

Anseeuw, W., L. A. Wily, L. Cotula, and M. Taylor. 2012. Land Rights and the Rush for Land: Findings of the Global Commercial Pressures on Land Research Project. ILC, Rome.

Editorial Code and Data Inc. 2012. Waste and scrap exports. http://www.marketsize.com/blog/index.php/category/international-trade/. Market Size Blog.

European Environment Agency. 2007. Freight transport demand- outlook from OECD. http://www.eea.europa.eu/data-and-maps/indicators/freight-transport-demand-outlookfrom-oecd/freight-transport-demand-outlook-from. EEA Management Plan.

FAO. 2012. Global trends and future challenges for the work of the organization. http://www.fao.org/docrep/meeting/025/md883E.pdf.

Hinrichsen, D. 2010. The world comes to town. http://www.peopleandplanet.net/?lid=26729\&section=40\&topic $=44$. People \& the Planet, London, UK.

Hulme, P. E. 2009. Trade, transport and trouble: managing invasive species pathways in an era of globalization. Journal of Applied Ecology 46:10-18.

Lawlor, K. and L. Olander. 2009. U.S. Government Funding for Forests in Developing Countries and the New REDD+ Landscape.

http://nicholasinstitute.duke.edu/climate/policydesign/u.s.-government-funding-forforests-in-developing-countries-and-the-new-redd-landscape. Duke, Nicholas Institute for Environmental Policy Solutions.

Molnar, A., S. J. Scherr, and A. Khare. 2004. Who conserves the world's forests? Communitydriven strategies to protect forests \& respect rights. Forest Trends, Washington, D.C.

UNCTAD. 2012. Global investment trends- chapter 1. http://www.unctaddocs.org/files/UNCTAD-WIR2012-Chapter-I-en.pdf. World investment report 2012: Towards a new generation of investment policies.

World Tourism Organization. 2009. Tourism and migration- Exploring the relationship between two global phenomena. World Tourism Organization, Madrid, Spain. 